\title{
THE INFLUENCE OF COMPETENCE TOWARD EMPLOYEE PERFORMANCE IN HARBORMASTER'S OFFICE AND PORT AUTHORITY
}

\author{
Anwar* \\ Master's Study Program of Management, University of Mataram, Mataram, \\ West Nusa Tenggara, Indonesia \\ Hermanto, Saufi Akhmad \\ Department of Management, Faculty of Economics and Business, University of Mataram, \\ Mataram, West Nusa Tenggara, Indonesia \\ *E-mail: hanwarmm2019@gmail.com
}

\begin{abstract}
This study aims to understand and analyze the significance of competencies (technical competencies, managerial competencies and cultural social competencies) to employee performance in Harbormaster's Office and Port Authority (KSOP) of Bima, West Nusa Tenggara Province. In its objective framework, the research respondents are not only KSOP internal employees, but also users in providing employee competency and performance. The total respondents were $44 \mathrm{KSOP}$ of Bima employees and 15 users. The validity test of the questionnaire was carried out on relatively similar organizations, namely KSOP of Badas, consisting of $30 \mathrm{KSOP}$ of Badas employees and 5 users. The analysis tool uses multiple linear regression analysis. Obtained from technical, managerial and social competencies, as well as significant and simultaneous on the performance of KSOP employees. Management of these permits together or in part can improve employee performance. Management focus can be made on managerial competencies, because it provides a dominant influence, amounting to $17.31 \%$. The influence of the competencies of the three competencies is quite large $(46.30 \%)$ on performance. KSOP of Bima management needs to develop competencies throughout the year, both through formal and informal training by managing internal organizations. It can also be done by gap performance analysis with competencies, so as to improve competencies according to the needs of the organization and employees.
\end{abstract}

\section{KEY WORDS}

Competencies, technical, managerial, socio-cultural, performance, harbormaster.

The direction of development in Indonesia still requires an orientation that is in harmony with its potential, so that it can accelerate the function of the state in realizing public welfare. The focus of development has been oriented on land, in all aspects, both concerning the construction of facilities and infrastructure and the exploration of their potential. Empirical facts Indonesia is an archipelagic country with a greater quantity and potential of marine resources than the land sector. Indonesia consists of 17,508 islands, a coastline of 81,290 $\mathrm{km}$ with an area of 5.8 million $\mathrm{km} 2$. Development on land must be oriented to support the existence of Indonesia as an archipelagic country, not merely by land orientation. Attention needs to be paid to port development, excavation of economic resources in the sea, including the development of a marine tourism economy based on creativity and raising awareness of the apparatus and the community in using it.

The government in utilizing marine potential is not only from the physical aspect, the availability of natural resources, but also non-physical. The existence of Indonesia which is flanked by two continents (the Continent of Asia and the Continent of Australia) and also two oceans (Indian Ocean and Pacific Ocean) must be utilized and create profits, so it is not just a slogan. Sustainable development of each regime also needs to be a concern, not development that is independent in nature, so that there is strengthening in development based on the potential of the nation. This is confirmed, because the development platform 
oriented to say maritime has been carried out, at least in legislation since 1996 with the issuance of Law No. 6 of 1996 and its operationalization through Government Regulation No. 37 of 2002. In the legislation, Indonesia was divided into three Indonesian Archipelago Sea Grooves (ALKI). The Indonesian Archipelago Sea Channel (ALKI) is a "sea channel that is passed by a foreign ship or aircraft above the sea channel, to carry out shipping and flights in the normal way solely for continuous transit, directly and as quickly as possible and not blocked through or above the archipelagic waters and adjacent territorial seas between one part of the high seas or the Indonesian Exclusive Economic Zone and other parts of the high seas or Indonesian Exclusive Economic Zones.

NTB Province is in ALKI II (paragraph 3 article 11 of PP No. 37 of 2002 concerning the Rights and Obligations of Foreign Aircraft Vessels in Implementing the Rights of the Archipelago Sea Groove Through the Islands Sea Lines Defined by the President of the Republic of Indonesia). ALKI II is used for shipping from the Sulawesi Sea across the Makassar Strait, Flores Sea and Alas Strait to the Indian Ocean and vice versa. The existence of the NTB Province through the ALKI II Indonesia route will create a lot of transfortasi sea with various destinations and needs to cross or come to NTB Province, because with the ALKI II this will provide access to facilities and smoothness and security of shipping on the route. In the context of regional autonomy, the NTB Province government must be optimal in directing development that is oriented to the utilization of the intended marine potential. In the tourism sector, NTB Province is located in three international tourist destinations, namely Bali, Komodo Island and Toraja (BAPPEDA NTB, 2014). NTB Province has the same superiority in the marine sector nationally, so its role is to strengthen national economic policies for accelerating development in the NTB region.

Conscious of these marine potentials, the existence of public organizations that manage marine affairs is very important to pay attention to their performance. One of them is the performance of KSOP (Office of the Port Authority and Port Authority) of Bima, through the improvement of individual employee performance. The existence of Bima KSOP is very important to support the economic development of Bima Regency and NTB Province on a regional scale and contribute to the national economy. This position can be seen from the existence of the NTB Province as the National Gate in the Corridor V (Master Plan for the Acceleration and Expansion of Indonesian Economic Development) (BAPPEDA NTB, 2014).

Performance is the achievement of results, the final goal is directed by activities (means) that are useful "(Sofo, 2003). Optimal performance shows the results of human expertise, knowledge and competence (Rothwell and Kazanas, 1992 in Sofo, 2003). In line with Robbins's statement (2003) that performance is a function of ability, motivation and opportunity $[P=f(A, M, O)]$. Competency is relevant to ability, that the development of performance is a manifestation of employee competency development (Sofo, 2003). Competence is "tools and resources belonging to workers that can be used to create value" (Hartanto, 2009). In the context of legislation (article 69 of Law No. 5 of 2014) that competencies must be possessed by state apparatus in the form of technical competencies, managerial competencies and cultural social competencies.

Sarwoko, et al (2013) also found that competence had a significant and positive effect on organizational performance. Gabriela (2014) also found that competence has a significant effect on organizational performance. The results of the study regarding the influence of competency on performance are still gaps. Osei and Ackah (2015) found that social competence and training results did not significantly influence organizational performance. This research gap is the basis for conducting further research on the effect of competency on performance. This research is also needed, because there is still an empirical gap that the KSOP Bima still has not been able to realize high performance. It is proven by the fact that there are still many people who choose land routes in transportation to support the economic sector of the community and have not been optimal in exploring other sectors, such as creative maritime tourism. The formulation of the problem in this study is "is there a significant effect of competencies (technical competence, managerial competence and cultural social competence) on employee performance on KSOP Bima"?. 


\section{LITERATURE REVIEW}

Klemp in Hartanto (2009) defines competence as "a person's characteristics that produce effective or superior performance at the time of carrying out a job". Competence is not limited to being able to complete work in accordance with the field of work, but is able to exceed the task burden, thus getting superior criteria in completing work. Competence in this study refers to the dimensions stipulated in article 69 of Law No. 5 of 2014, consisting of 1) technical competence; measured by the level and specialization of education, functional technical training, and experience working technically; 2) managerial competence; measured from the level of education, structural or management training, and leadership experience; and 3) cultural social competencies; measured from work experience related to plural societies in terms of religion, ethnicity, and culture so that they have national insight.

The items or indicators of the three dimensions of competency will be adjusted, because competencies related to proof of work are not merely formal and conceptual from knowledge alone. This has become a problem of measuring competency in public organizations so far, because it is only formal and structural. Absolute competency is related to the ability to create value, by doing the best work and tasks (Hartanto, 2009). Based on this, the measurement of competency should be based on the outcome of the work, including the party giving the assessment is the party who feels the results of his work. In this study the management of the company became KSOP of Bima's partner.

In this study, employee competencies are directed at improving individual performance, which has implications for organizational performance. Performance, namely "the work that can be achieved by a person or group of people in an organization, in accordance with their respective authority and responsibility, in order to achieve the objectives of the organization in question legally, not violating the law and in accordance with morals and ethics" (Sedarmayanti, 2007). Hewitt assosiates in Sofo (2003) gives a statement of performance, namely "the function of work is producing results. If people know what needs to be done, get feedback related to success or failure and get an award for doing something that should have been done, the organization will tend to get more output and expected results ".

\section{METHODS OF RESEARCH}

The type of research used is associative research. The results of this study were directed to produce associative equations from the dimensions of competency (technical competence, managerial competence and cultural social competence to the performance of Bima KSOP employees. Observation data to form the model in the form of all the number of Bima KSOP employees as many as 44 people and added with KSOP Bima users as much as 15 people, so that the total observation data (research subjects) were 59. Data collection tools used questionnaires containing indicators / items from each variable. The test of validity was carried out on a level organization, namely KSOP Badas. Research procedures by first testing the validity and reliability. Furthermore, only using valid indicators as the basis for measuring variables. The analysis tool uses multiple linear regression analysis, by first performing a classic assumption test (normality test, multicollinearity test and heteroscedasticity test). Then test the significance and utilization of parameters produced by the printout regression through the SPSS program.

\section{RESULTS AND DISCUSSION}

Based on the $F$ test for the simultaneous test it was found that the $F$ test was 15.785 , while the $F$ table was 2.76, meaning that the $F$ test $>F$ table, so the testing criteria received were Ha. This means that there are simultaneous significant effects of the dimensions of competency (technical competence, managerial competence and cultural social competence) on the performance of employees of KSOP Bima.

Partial significance test with $t$ test found that the value of $t$ test technical competence $(X 1)=2,921$; managerial competence $(X 2)=3,389$ and cultural social competence $(X 3)=$ 
$2,377)$ of each variable is greater than t table $(1,96)$. The testing criteria received are $\mathrm{Ha}$, meaning that the dimensions of competency (technical competence, managerial competence and cultural social competence) have a partially significant effect on the performance of KSOP Bima employees. The hypothesis in this study was that all of them proved correct or accepted.

The coefficient of partial determination (r2XiY) gives the level of influence of each variable partially on the performance of KSOP Bima employees. The value of $\mathrm{r} 2 \mathrm{X} 1 \mathrm{Y}=$ $13.41 \%, r 2 X 2 Y=17.30 \%$; and $r 2 X 3 Y=9.30 \%$, indicating that the dimensions of employee competency that provide the dominant influence in the form of managerial competence. The level of influence of the three competency dimensions is $46.30 \%$ (simultaneous determination coefficient).

Management of the competency dimensions of employees of KSOP Bima can be a concern, because it is able to provide variations in performance changes of $46.30 \%$ (R2 value; coefficient of simultaneous determination). This shows that the level of influence given is quite high. The orientation in improving the competency dimension starts from managerial competence, technical competence and cultural social competence, in accordance with the level of influence given partially to the performance of KSOP Bima employees.

The findings of the level of influence of the competency (technical, managerial and social cultural) dimensions of Bima KSOP employees on their performance of $46.30 \%$ indicate that there are influences from other factors of $53.70 \%$. Referring to the number of factors that influence performance, for example from the Robbins model (2003), it means there are motivations and opportunities. Based on the Gibson et al model. (1997) that competence is a small part of the individual dimension, including the dimensions of the work and non-work environment.

The existence of random variables (other variables) that affect the performance of employees with a considerable amount, the ability of the competency dimensions (technical, managerial and social culture) in influencing the performance of Bima KSOP employees by $46.30 \%$ is very important to be considered by management. Employee development is carried out continuously every year according to performance planning, determining the performance gap is done simultaneously with the performance evaluation, so that employee competency development programs can be carried out.

The implementation of the results of this study is that the management of Bima KSOP must implement an employee competency development policy. The development of these competencies is carried out continuously, not an insedental one. This is important to do, not limited to improving the technical, managerial and socio-cultural capabilities of employees, but it has implications for the performance of employees who will contribute to organizational performance. The further implication is that organizations can develop in utilizing every opportunity.

KSOP Bima in the practice of carrying out duties is not only for the security and smooth transportation of agricultural, plantation and livestock commodities from Bima Regency. KSOP Bima must position itself as part of the formation of the economy on a broader scale, both in the context of the region or field. KSOP Bima must emerge as a party capable of taking part in introducing tourism potential in NTB Province, especially marine tourism potential. In this context, employee competencies must be developed in line with the fields to be strengthened. There is a lot of potential for the marine sector that can be introduced by Bima KSOP which contributes to increasing income directly, creating jobs, so that regional economic growth increases. The development of technical, managerial and socio-cultural competencies of Bima KSOP employees will be able to benefit from the existence of NTB province as part of ALKI II, its existence in three world tourism routes (Bali, Komodo and Toraja), so that every tourist who needs to be introduced should not less attractive than other tourist destinations. There are also marine tourism destinations, cultural values and others that are well known and will be introduced at the world level, such as moyo tourism in Sumbawa, Lake and others.

Employee competencies (technical, managerial and social cultural) are not only used to obtain economic opportunities in the real sector and tourism, but also absolutely necessary 
to minimize the various negative impacts that exist. Managerial competencies related to the ability to use all potential employees, work together to support each other in identifying possible negative behaviors of users (smuggling, human tracking and others). Technical capability is continuously improved in a variety of technical expertise, so that it quickly identifies possible negative aspects of the security and smoothness of shipping, the other side is the security of the general public for the activities of the users. The ability to work in a pluralistic cultural environment must always be embedded in a national attitude, objective in meaning in favor of the state's goals in carrying out their duties, so that individuals who find it difficult to manipulate their decision to check, allow shipping and other port activities.

Employee KSOP Bima's competency development is very possible, because the process is carried out in stages and there is strong potential from the employees. Preliminary findings have shown that technical competence, managerial competence and cultural social competencies of Bima KSOP employees are high, although they are still in the early stages of these criteria. The right and continuous competency development policy is not only limited to improving performance, but also increasing organizational contributions (KSOP Bima) in its presence in ALKI II or its role in economic development in accordance with the existence of NTB Province in the National Gate in MP3EI (Master Plan for Acceleration and Expansion of Indonesian Economic Development) Corridor V.

\section{CONCLUSION}

The conclusions in this study are, it is proven that technical competence, managerial competence and cultural social competence have a significant and positive effect on the performance of KSOP Bima employees. The significance of the effect is proven through the $t$ test, where the criteria received are $\mathrm{Ha}$. Positive influences are seen from the regression coefficients generated in the equation or the performance model is positive. Management of the competency dimensions that will improve / improve them will have an impact on improving the performance of KSOP Bima employees.

In accordance with these conclusions, the suggestions in this study are the performance of Bima KSOP employees can be improved through continuous development of employee competencies, both formally and informally within the organization. Formally done through formal training by analyzing the needs of the organization and individual employees. Creating environmental conditions that support managerial and social cultural competencies, so that all potential human resources in the organization can be maximized in realizing organizational goals, including maximizing relationships with external parties. The management conducts a performance gap analysis associated with competency gaps, so that targeted competency development can be applied in supporting the performance of KSOP Bima. For the next researcher can focus on examining the dimensions or antecedents of competence. In this study, it has been proven that competence has a significant effect on performance, so research that is focused on developing employee competencies is needed.

\section{REFERENCES}

1. 2002. PP No. 37 Tahun 2002 tentang Hak and Kewajiban Kapal Udara Asing dalam Melaksanakan Hak Lintas Alur laut Kepulauan Melalui Alur Laut Kepulauan yang Ditetapkan Presiden Republik Indonesia. Jakarta.

2. 2014. Undang-undang Republik Indonesia No. 5 Tahun 2014 tentang Aparatur Sipil Negara. Jakarta.

3. BAPPEDA NTB, (2014). Rencana Induk Pariwisata Berkelanjutan Pulau Lombok 20152019. Mataram.

4. Gabriela, K., (2014). The Relationship between Competency And Performance. Journal ACTA. Vol.62. No.6. pp. 60-68.

5. Ghozali, I., (2013). Aplikasi Analisis Multivariate dengan Program SPSS. Semarang: Badan Penerbit Universitas Diponegoro.

6. Gibson L. James, dkk., (1997). Organisasi; Perilaku, Struktur, Proses. Jakarta: Bina 
Aksara.

7. Hartanto, F.M., (2009). Paradigma Baru Manajemen Indonesia; Menciptakan Nilai dengan Bertumpu pada Kabajikan and Potensi Insani. Bandung: PT. Integre Quadro.

8. Kartika, L.N., and Sugiarto, A., 2014. Pengaruh Tingkat Kompetensi Terhadap Kinerja Pegawai Administrasi Perkantoran. Jurnal Ekonomi and Bisnis. Vol. XVII. No.1. pp. 7490.

9. Kementerian Pendayagunaan Aparatur Negara and Reformasi Birokrasi (2017). Implementasi Peraturan Pemerintah No. 11 Tahun 2017 tentang Manajemen PNS. Jakarta.

10. Mahmudi, (2007), Analisis Laporan Keuangan Pemerintah Daerah; Panduan Bagi Eksekutif, DPRD and Masyarakat dalam Pengambilan Keputusan Ekonomi, Sosial and Politik, Yogyakarta:UPP, AMP YPKN.

11. Makawi, U., dkk (2015). Analisis Pengaruh Kompetensi terhadap Kinerja Pegawai Dinas Perindustrian and Perdagangan Kota Banjarmasin. Jurnal Al-Ulum Ilmu Sosial and Humaniora. Vol. 1. No.1. pp. 16-26.

12. Muhidin, S.A. and Abdurahman, M., (2007). Analisis Korelasi, Regresi and Jalur dalam Penelitian. Bandung: CV. Pustaka Setia.

13. Osei, A.J., and Ackah, O., (2015). Employee's Competency And Organizational Performance In The Pharmaceutical Industry An Empirical Study Of Pharmaceutical Firms In Ghana. International Journal of Economics, Commerce and Management. Vol.3. No. 3. pp.1-9.

14. Nurmasitha, F., (2016). Pengaruh Kompetensi Pegawai and Lingkungan Kerja Terhadap Kualitas Pelayanan (Studi pada Dinas Kependudukan and Pencatatan Sipil Kabupaten Sidoarjo). Jurnal Administrasi Publik. Vol.1. No.2. pp.1220-1228.

15. Robbins, P.S., (2003). Perilaku Organisasi. Jakarta: PT. Indeks.

16. Sarwoko, E., dkk., (2013). Entrepreneurial Characteristics and Competency as Determinants of Business Performance in SMEs. Journal of Business and Management. Vol. 7.No. 3. pp. 31-38.

17. Sedarmayanti, (2014). Manajemen Sumber Daya Manusia, Reformasi Birokrasi and Manajemen Pegawai Negeri Sipil. Bandung: PT.Refika Aditama.

18. Sobari, A.R., (2018). Pengaruh Kopetensi and Motivasi Kerja terhadap Kualitas Pelayanan Dinas Kependudukan and Catatan Sipil Kota Bogor. Jurnal Lentera Bisnis. Vol. 7. No. 2. pp.126-138.

19. Umar, H., (2008). Metode Penelitian untuk Skripsi and Tesis Bisnis. Jakarta:Raja Wali Press.

20. Veriyanti, P.D., dkk., (2014). Pengaruh Kompetensi Sosial Terhadap Kinerja Pegawai Negeri Sipil Di Badan Kepegawaian Daerah Kabupaten Buleleng Tahun 2013. Universitas Pendidikan Ganesha. Vol.4.No.1. pp.1-12.

21. Widarjono, A., (2010). Analisis Statistika Multivariat Terapan. Yogyakarta: UPP STIM YKPN.

22. Yulianti, D., (2015). Pengaruh Kompetensi Sumber Daya Manusia Terhadap Kualitas Pelayanan Jasa Dokumen Impor di PT. Sarana Publik Logistik Jakarta. The Indonesian Journal of Public Administration. Vol. 1. No.1. pp. 89-97.

23. Zaim, H., et al., 2013. Analyzing the Effects Of Individual Competencies On Performance: A Field Study In Services Industries In Turkey. Journal of Global Strategic Management. Vol.7. No.2. p. 67-77. 